\title{
First record of the family Gigaspermaceae (Bryophyta) in Brazil
}

\author{
Denilson Fernandes Peralta ${ }^{1,5}$, (D) Juçara Bordin², (D) Daiane Valente Valente ${ }^{3}$, \\ D Paulo Eduardo Aguiar Saraiva Câmara ${ }^{3}$ e (1) Michael Stech ${ }^{4}$
}

Recebido: 27.01.2020; aceito: 17.04.2020

Como citar: Peralta, D.F., Bordin, J., Valente, D.V., Câmara, P.E.A.S. \& Stech, M. 2020. First record of the family Gigaspermaceae (Bryophyta) in Brazil. Hoehnea 47: e102020. http://dx.doi.org/10.1590/2236-8906-10/2020.

ABSTRACT - (First record of the family Gigaspermaceae (Bryophyta) in Brazil). Lorentziella imbricata (Mitt.) Broth. belongs to the family Gigaspermaceae and is a common plant in the subtropical regions of the Noth and South America. This plant can be characterized by presenting leafy stems arising from subterranean rhizomatous axes, pale green or often whitish leaves, and sessile large capsules with large spores. This is the first citation of the genus Lorentziella and the family Gigaspermaceae for Brazil, found during field collections in the Pampa biome, state of Rio Grande do Sul.

Keywords: bryophytes, Bryopsida, cleistocarpy, APA of Ibirapuitã

RESUMO - (Primeiro registro da família Gigaspermaceae (Briófita) no Brasil). Lorentziella imbricata (Mitt.) Broth. pertence a Gigaspermaceae e é uma planta comum nas regiões subtropicais da América do Norte e do Sul. É caracterizada pelos caulídios com filídios surgindo a partir de eixos rizomatosos subterrâneos, filídios verde-pálidos a frequentemente brancos e pelas cápsulas grandes e sésseis que produzem esporos grandes. Esta é a primeira citação do gênero Lorentziella e da família Gigaspermaceae para o Brasil. Esta ocorrência foi registrada durante coletas em campo no Bioma Pampa, no Estado do Rio Grande do Sul.

Palavras-chave: briófitas, Bryopsida, cleistocarpia, APA do Ibirapuitã

\section{Introduction}

The moss family Gigaspermaceae (Bryopsida, subclass Gigaspermidae) is found predominantly in the Southern Hemisphere (Sharp et al. 1994). These plants are characterized by leafy stems arising from subterranean rhizomatous axes, pale green, often whitish leaves, and big sessile capsules producing large spores (Stech \& Frey 2009, Brugués 2010). The family comprises six to nine species, distributed in five (traditionally six) small, mostly monospecific genera: Chamaebryum Thér. \& Dixon, Costesia Thér., Gigaspermum Lindb., Neosharpiella H. Rob. \& Delgad. (nowadays placed in Bartramiaceae), Oedipodiella Dixon, and Lorentziella Müll. Hal. ex Besch. (Fife 1980, Stech \& Frey 2009). Of these, Gigaspermum, Lorentziella, and Neosharpiella occur in the Neotropics, from Mexico to southern South America (Gradstein et al. 2001). In Brazil, however, there were no records of Gigaspermaceae.

Lorentziella is characterized by plants with distally imbricate, concave, broadly ovate to elliptic leaves that are abruptly narrowed to a long awn; a narrow costa extending to the base of the awn and immersed to slightly emergent capsules with truncate base and undifferentiated operculum (Larrain et al. 2017). According to Gradstein et al. (2001), and Frey \& Stech (2009) Lorentziella is monospecific (only L. imbricata), with occurrences registered for southern United States, Mexico, Uruguay, Paraguay and Argentina (Fife 1980, Gradstein et al. 2001). This work aims to report the first record of Lorentziella imbricata (Mitt.) Broth. and the family Gigaspermaceae to Brazil.

1. Instituto de Botânica, Avenida Miguel Estefno, 3687, Água Funda, 04301-902 São Paulo, SP, Brasil

2. Universidade Estadual do Rio Grande do Sul, Unidade Litoral Norte-Osório, Rua Machado de Assis, 1456, 95520-000 Osório, RS, Brasil

3. Universidade de Brasília, Departamento de Botânica, Laboratório de Criptógamas, Campus Universitário Darcy Ribeiro, 70910-900 Brasília, DF, Brasil

4. Naturalis Biodiversity Center, Darwinweg 2, 2333 CR Leiden, Netherlands

5. Corresponding author: denilsonfperalta@gmail.com 
Samples were collected at the municipality of Santana do Livramento, in the Environmental Protection Area (APA) of Ibirapuitã, Rio Grande do Sul State, Brazil, 30 46'0.47'S and $55^{\circ} 34^{\prime} 47.7^{\prime \prime} \mathrm{W}$. The APA of Ibirapuitã is a direct use Conservation Unit (created in 1992 by Decree No. 529 of May 20, 1992), with an area of $316,790,42$ hectares. It is located in the southwest region of the state of Rio Grande do Sul, within the Pampa biome.

The collections were performed with the aid of spatulas to remove the specimens together with the substrate. The samples were kept at room temperature for drying. Identification was performed with the aid of a microscope and optical stereo microscope, using specialized literature and identification keys. The samples were deposited in the Herbarium Instituto de Botânica de São Paulo (SP).

Lorentziella imbricata (Mitt.) Broth., Nat. Pflanzenfam. I(3):

511. $1903 \equiv$ Leptangium imbricatum Mitt., J. Linn. Soc.,

Bot. 12: 240. 1869. Type: Uruguay, Montevideo, Gibert

714 [Lectotype NY barcode NY00968176, designated

by Fife (1980); Isolectotype PC barcode PC0696100]. Figure 1 and Figure 2
Gametophytes small, firm, forming dense tufts, dark green. Stem erect, sparsely branched, ramifications mostly short, densely tomentose at the base, cross-section showing no central band of stereids. Leaves lanceolate, spiral, acute apex, entire margin; costa narrow, long excurrent, often hyaline; short hexagonal cells, thin cell wall. Perichaetium terminal, leaves 2-4 times larger than vegetative. Capsule immersed, globose, smooth, and wrinkled when dry, cleistocarpic.

Material examined: BRAZIL: Rio Grande do Sul, APA do Ibirapuitã, 02/IX/2017, em barranco, Peralta, D.F. et al. 21224, 21262 (SP).

The number of bryophytes species occurring in Brazil was based on literature and herbarium specimens. Many of these names are now synonyms and, after several efforts, Costa \& Peralta (2015) reported 1,571 species to Brazil, of which 15 were hornworts, 674 liverworts, and 882 mosses ( $10 \%$ of all known bryophytes in the world). The latter authors excluded 603 names, indicating the need for revisional works (Gradstein \& Costa 2003, Costa et al. 2011).

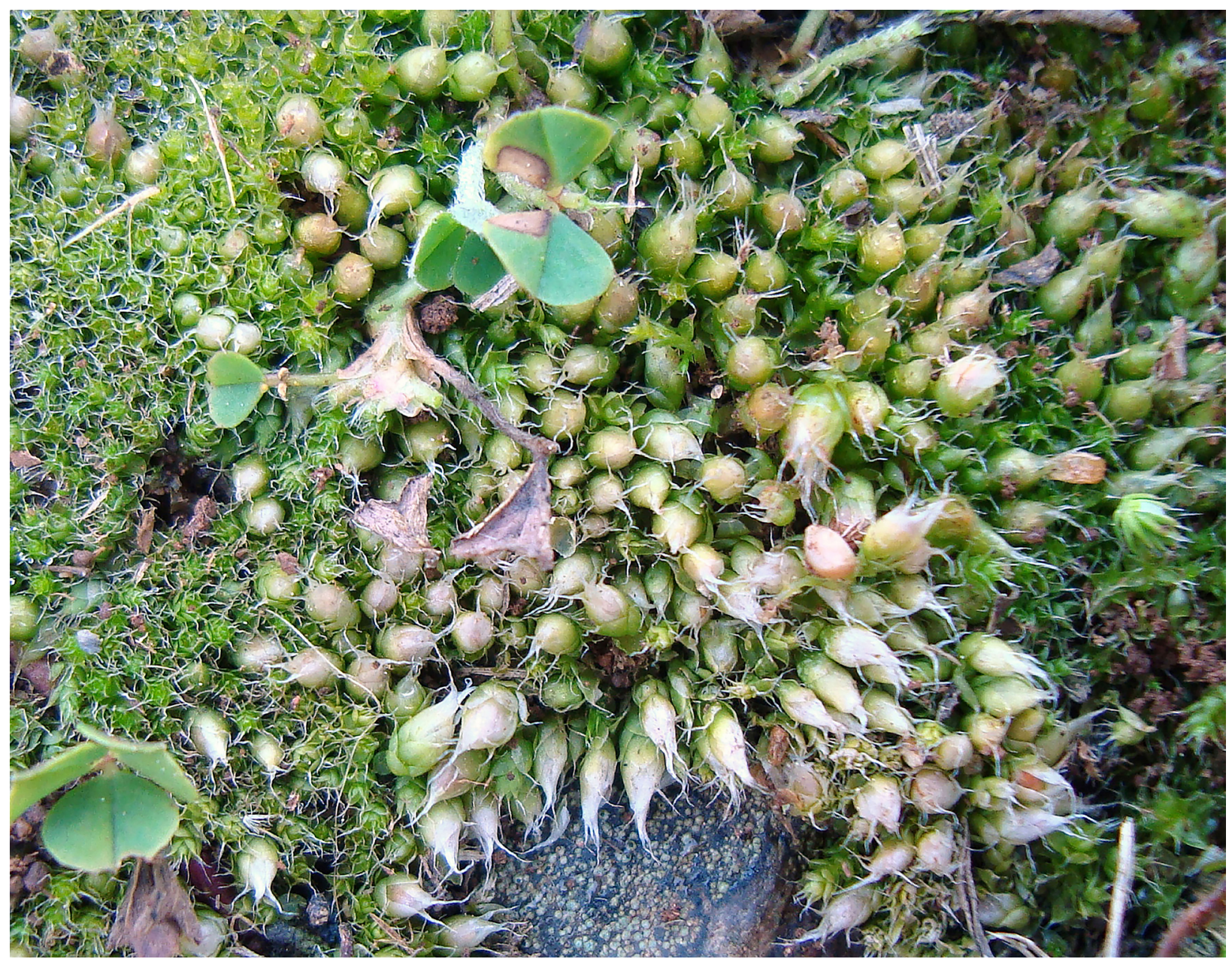

Figure 1. Field picture of Lorentziella in the Environmental Protection Area of Ibirapuitã (APA), Rio Grande do Sul State, Brazil. The perichaetial leaves have a whitish aspect. 


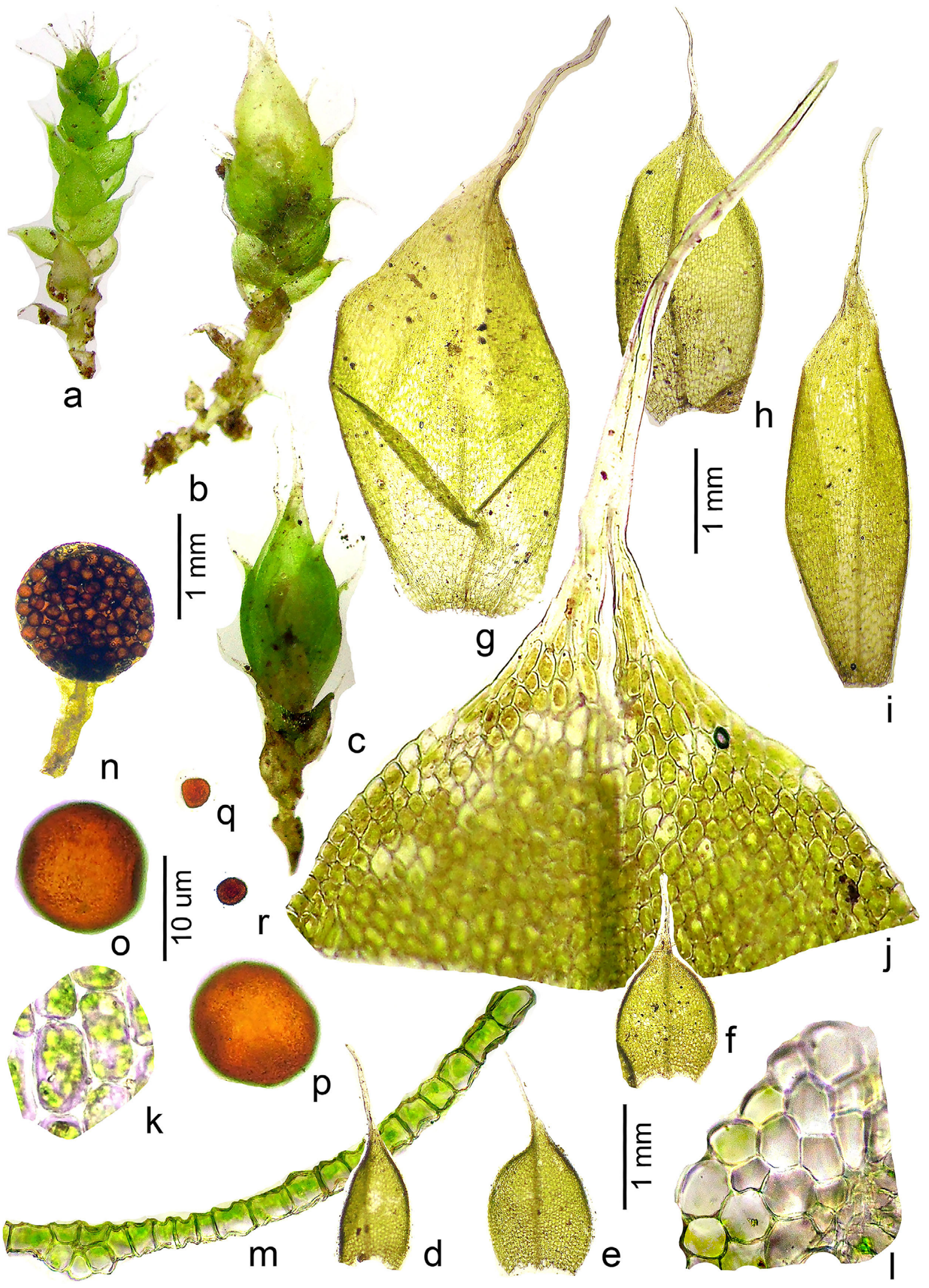

Figure 2. Lorentziella imbricata (Mitt.) Broth. a. Gametophyte with sporophytes. b-c. Gametophyte with perichaetial leaves. c-f. Stem leaves. g-i. Perichaetial leaves. j. Apical cells of the leaf. k. Laminal cells of the leaf. 1. Stem in cross-section. m. Leaf in cross-section at the median region. n. Capsule with a seta. o-p. Spores. q-r. Abortive spores. 
Gametophytes were found on the soil between rocky outcrops, grasses, Selaginella, and other cleistocarpic capsulate bryophytes (Archidium Brid., Leptophascum (Müll. Hal.) J. Guerra \& M.J. Cano) and Riccia L., with altitudes ranging from $150-200 \mathrm{~m}$.

Larrain et al. (2107) presented nomenclatural updates and disjoint phytogeographic characterization of Lorentziella imbricata between the two subtropical portions of North and South America. Larrain et al. (2017) did not cite Brazilian samples and thus the occurrence of this genus remained unknown for Brazil.

Gigaspermaceae was not yet worldwide reviewed. The species currently recorded was firstly identified as Lorentziella because its cleistocarpic capsule differentiates from the nearest genus, Gigaspermum, which has a 'gymnostoma' capsule as described by Larrain et al. (2017) and Seppelt et al. (2012).

Lorentziella's distribution includes Uruguay, Paraguay, Argentina (Lawton 1953, Fife 1980), Bolivia (Fuentes \& Muñoz 2002, Churchill \& Fuentes 2005), Chile, Central Mexico (Cardenas \& Delgadillo 1994) and Texas (Lawton 1953, Rushing \& Snider 1980, Rushing 2007). The new record shows its importance by increasing the knowledge about the bryoflora of the Pampa biome, which is one of the less floristically studied in Brazil. It increases the knowledge of the Brazilian biodiversity as well.

\section{Acknowledgments}

To the DNA-Barcoding Project of Brazilian bryophytes - A case study to improve the identification of tropical bryophyte species, funded by MEC/MCTI/CAPES/CNPq/ FAPs No. 71/2013.

\section{Literature cited}

Brugués, M. 2010. Gigaspermaceae. En: J. Guerra, M.J. Cano \& R.M. Ros (Eds.), Flora Briofítica Ibérica. vol. 4: 29-33.

Cardenas, A. \& Delgadillo M., C. 1994. Lorentziella imbricata and Oreoweisia delgadilloi in Mexico. The Bryologist 97: 85-86.
Churchill, S.P. \& Fuentes, A. 2005. Additions, combinations, and synonyms for the Bolivian moss flora. Tropical Bryology 26: 119-131.

Costa, D.P. \& Peralta, D.F. 2015. Bryophytes diversity in Brazil. Rodriguésia 66(4): (DOI: 10.1590/21757860201566409).

Costa, D.P., Pôrto, K.C. et al. 2011. Synopsis of the Brazilian moss flora: checklist, distribution and conservation. Nova Hedwigia 93(3-4): 277-334.

Fife, A.J. 1980. The Affinities of Costesia and Neosharpiella and Notes on the Gigaspermaceae (Musci). The Bryologist 83: 466-476.

Frey, W. \& Stech, M. 2009. Marchantiophyta, Bryophyta, Anthocerotophyta. In: Frey, W. (ed.): Syllabus of Plant Families. A. Engler's Syllabus der Pflanzenfamilien, $13^{\text {th }}$ ed., Part 3 Bryophytes and seedless Vascular Plants, pp. 13263. Gebr. Borntraeger Verlagsbuchhandlung, Stuttgart.

Fuentes, A. \& Muñoz, J. 2002. Contribution to the bryoflora of Bolivia. I. Lowland mosses from two protected areas in the Department of Santa Cruz. Journal of Bryology 24: 165-167.

Larrain, J., Fife, A. et al. 2017. Lorentziella (Gigaspermaceae, Bryophyta) new for Chile, and lectotypification of the genus. Boletín de la Sociedad Argentina de Botánica 52(2): 51-355.

Lawton, E. 1953. Lorentziella, a moss genus new to North America. Bulletin of the Torrey Botanical Club 80: 279-288.

Rushing, A.E. 2007. Gigaspermaceae. In: Flora of North America Editorial Committee (eds.), Flora of North America, vol. 27, Bryophyta, part 1, pp. 202-203. New York: Oxford University Press.

Rushing, A.E. \& Snider, J.A. 1980. Observations on sporophyte development in Lorentziella imbricata (Mitt.) Broth. Journal of the Hattori Botanical Laboratory 47: 35-44.

Seppelt, R.D., Cave, L.H. \& Tng, D. 2012. Here today, gone tomorrow: the moss Gigaspermum repens in Tasmania. Kanunnah 5: 141-149.

Sharp, A.J., Crum, H.A. \& Eckel, P.M. 1994. The moss flora of Mexico. Memoirs of The New York Botanical Garden 69(1-2): 1-1113. 